\title{
Article \\ Cytogenomics of Deschampsia P. Beauv. (Poaceae) Species Based on Sequence Analyses and FISH Mapping of CON/COM Satellite DNA Families
}

\author{
Alexandra V. Amosova *(D), Lilit Ghukasyan, Olga Yu. Yurkevich (D), Nadezhda L. Bolsheva, Tatiana E. Samatadze (D), \\ Svyatoslav A. Zoshchuk and Olga V. Muravenko \\ Engelhardt Institute of Molecular Biology, Russian Academy of Sciences, 32 Vavilov St, 119991 Moscow, Russia; \\ lilitghukasyan90@gmail.com (L.G.); olikys@gmail.com (O.Y.Y.); nlbolsheva@mail.ru (N.L.B.); \\ tsamatadze@gmail.com (T.E.S.); slavazo@mail.ru (S.A.Z.); olgmur1@yandex.ru (O.V.M.) \\ * Correspondence: amomar@mail.ru; Tel.: +7-495-135-0439
}

check for updates

Citation: Amosova, A.V.; Ghukasyan, L.; Yurkevich, O.Y.; Bolsheva, N.L.; Samatadze, T.E.; Zoshchuk, S.A.; Muravenko, O.V. Cytogenomics of Deschampsia P. Beauv. (Poaceae) Species Based on Sequence Analyses and FISH Mapping of CON/COM Satellite DNA Families. Plants 2021, 10, 1105. https://doi.org/10.3390/ plants10061105

Academic Editors: Tomás Naranjo, Khalid Meksem and Ekaterina D. Badaeva

Received: 15 April 2021

Accepted: 26 May 2021

Published: 30 May 2021

Publisher's Note: MDPI stays neutral with regard to jurisdictional claims in published maps and institutional affiliations.

Copyright: (c) 2021 by the authors. Licensee MDPI, Basel, Switzerland. This article is an open access article distributed under the terms and conditions of the Creative Commons Attribution (CC BY) license (https:/ / creativecommons.org/licenses/by/ $4.0 /)$.
Abstract: The genus Deschampsia P. Beauv. (Poaceae) involves a group of widespread polymorphic species, and many of them are highly tolerant to stressful environmental conditions. Genome diversity and chromosomal phylogeny within the genus are still insufficiently studied. Satellite DNAs, including CON/COM families, are the main components of the plant repeatome, which contribute to chromosome organization. For the first time, using PCR-based (Polymerase Chain Reaction) techniques and sequential BLAST (Basic Local Alignment Search Tool) and MSA (Multiple Sequence Alignment) analyses, we identified and classified CON/COM repeats in genomes of eleven Deschampsia accessions and three accessions from related genera. High homology of CON/COM sequences were revealed in the studied species though differences in single-nucleotide alteration profiles detected in homologous $\mathrm{CON} / \mathrm{COM}$ regions indicated that they tended to diverge independently. The performed chromosome mapping of 45S rDNA, 5S rDNA, and CON/COM repeats in six Deschampsia species demonstrated interspecific variability in localization of these cytogenetic markers and facilitated the identification of different chromosomal rearrangements. Based on the obtained data, the studied Deschampsia species were distinguished into karyological groups, and MSA-based schematic trees were built, which could clarify the relationships within the genus. Our findings can be useful for further genetic and phylogenetic studies.

Keywords: Deschampsia P. Beauv.; satellite DNA; CON/COM sequences; Multiple Sequence Alignment analysis; fluorescence in situ hybridization; chromosomes; interspecific variability

\section{Introduction}

The Aveneae/Poeae tribe complex comprises a large number of valuable crops and forage plants [1,2]. Many species of this tribe are polymorphic with a wide geographical distribution, high morphological diversity, and complicated taxonomy [3,4]. The genus Deschampsia P. Beauv. (Poaceae) comprises more than 30 widespread species, and most Deschampsia taxa are highly tolerant to stressful and variable environmental conditions including extreme Arctic and Antarctic regions [5-7]. Deschampsia antarctica E. Desv. is a perennial grass which occupies a vast area of the Southern Hemisphere including northern Patagonia, sub-Antarctic Islands, the west coast of the Antarctic Peninsula, and the Maritime Antarctic. Moreover, this species is one of two native angiosperms adapted to the severest Antarctic environments [7-10]. Polar and subpolar ecotypes of Deschampsia species could serve as a useful source of genes associated with stress tolerance and environmental adaptation, and investigation of the evolutionary changes which occurred in their genomes could provide insights into the genome history of closely related taxa important for crop breeding [11-14].

However, genome diversity and comparative chromosomal phylogeny within the genus Deschampsia are still insufficiently studied $[13,15,16]$. Besides, the complicated breed- 
ing system peculiar to the evolution process of major taxa within the Aveneae/Poeae tribe (e.g., interspecific and intergeneric hybridization events), could lead to the formation of new allopolyploids [17], and the details of the phylogeny among many genera related to Deschampsia and also suprageneric taxa still remain controversial [18]. Moreover, environmental stress factors can induce genetic changes followed by structural chromosomal variations (chromosome rearrangements, mixoploidy, and aneuploidy) in plant species $[16,19,20]$, and therefore, molecular cytogenetic characterization is a key component of the investigation of plant genomes [15,18].

Repetitive DNA (mostly transposable elements and tandem repetitive DNA (satellite DNA)) is one of the main components of genomes of vascular plants [21,22]. The identification and characterization of different satellite DNA families (satDNAs) in genomes of different taxa within the Aveneae/Poeae tribe are currently being studied intensively based on both molecular and cytogenetic levels, and physical mapping of specific satDNAs on individual chromosomes provides information on changes in genome structures which occurred during evolution [22-25].

CON1, CON2, COM1, and COM2 satDNAs, isolated from the genus Helictotrichon [26,27], are shared between many groups of the Aveneae/Poeae tribe complex highlighting their evolutionary significance. Particularly, CON/COM satDNAs were detected in genomes of Deschampsia cespitosa (L.) P. Beauv. and D. antarctica, and also several species from the genera related to Deschampsia [15,24,26-28]. Recently, we have performed a comparative molecular cytogenetic characterization of several Deschampsia species, which were sampled in different regions including extreme Antarctic (D. antarctica) and sub-Arctic areas (D. sukatschewii (Popl.) Roshev). The applied new approach, based on multicolor fluorescence in situ hybridization (MC-FISH) with $45 \mathrm{~S}$ and $5 \mathrm{~S}$ rDNA and also sequential rapid genomic in situ hybridization (rapid GISH) with genomic DNAs of closely related (D. antarctica and D. cespitosa) and the most distant (D. flexuosa (L.) Trin. (= Avenella flexuosa (L.) Drejer)) species helped us clarify the intra- and interspecific variations in their karyotypes and also detect different chromosomal rearrangements [16,19].

The present work aims to characterize CON/COM satDNA families from genomes of eleven Deschampsia accessions covering seven species and three plant accessions representing other related genera, and also perform FISH mapping of 45S rDNA, 5S rDNA, and CON/COM satDNAs in karyotypes of Deschampsia species to examine the interspecific variability in chromosomal localization of these DNA repeats and specify chromosomal structural changes which occurred within the genus Deschampsia during speciation.

\section{Results}

\subsection{PCR and BLAST Analysis}

For the first time, CON1, CON2, and COM2 satDNAs were identified and classified in genomes of the studied accessions. With the use of a PCR-based technique, CON1 and CON2 sequences were obtained for DNA samples of 13 studied accessions (Figures 1 and 2). COM2 sequences were clearly obtained for six DNA samples (D. cespitosa PI-577069, D. cespitosa PI-562652, Deschampsia parvula (Hook.f.) E. Desv., D. flexuosa, Kolleria macrantha (Ledeb.) Schult. (syn. Kolleria cristata (L.) Pers.), and T. phleoides) (Figure 3). 


\begin{tabular}{|c|c|c|c|c|c|c|c|c|c|c|c|}
\hline \multirow[b]{3}{*}{ Reference: D. antarctica } & \multicolumn{11}{|c|}{ Fragments with Single-Nucleotide Alterations Revealed in the Aligned CON1 Sequences } \\
\hline & & & & & & ATTGAACTGGT & & & & & \\
\hline & ACTITCTATGA & AGCTTGCCCTG & AACCAGCTCAT & AAACCTAGCTC & GCCAAGAAGTG & ATTGACCTGGT & TTGAACTGGT & T GTATGTAATTG & GCCCTGAAATC & GTCCCGGGACT & ACCGGAATCAT \\
\hline D. antarctica KEW-0522816 & $\mathrm{C}$ & G & G & $\mathrm{T}$ & G & $\mathrm{A} / \mathrm{C}$ & C & $\mathrm{T}$ & G & G & $\mathrm{A}$ \\
\hline D. antarctica KEW-0661919 & $\mathrm{C}$ & G & $G$ & $\mathrm{~T}$ & $G$ & $\mathrm{~A} / \mathrm{C}$ & $\mathrm{C}$ & $\mathrm{T}$ & $G$ & $G$ & $\mathrm{~A}$ \\
\hline D. antarctica KEW-0521613 & $\mathrm{C} / \mathrm{G}$ & G & $\mathrm{G}$ & $\mathrm{T}$ & G & $A / C$ & $\mathrm{c}$ & $\mathrm{T}$ & $\mathrm{G}$ & G & A \\
\hline D. parvula KEW-0661849 & $\mathrm{C}$ & $\mathrm{G}$ & G & $\mathrm{T}$ & $\mathrm{G}$ & $\mathrm{A} / \mathrm{C}$ & C & $\mathrm{T}$ & G & G & A \\
\hline D. sukatschewii 78 & C & G & $\mathrm{G} / \mathrm{T} / \mathrm{C}$ & $\mathrm{T}$ & $G$ & $\mathrm{~A} / \mathrm{C}$ & $\mathrm{C}$ & $T$ & $G$ & G & A \\
\hline D. cespitosa PI-562652 & $\mathrm{C}$ & G & $\mathrm{G} / \mathrm{T} / \mathrm{C}$ & $\mathrm{T} / \mathrm{A}$ & $\mathrm{G} / \mathrm{T}$ & $\mathrm{A}$ & $\mathrm{G} / \mathrm{C}$ & $\mathrm{T} / \mathrm{C}$ & $G$ & G & $\mathrm{A}$ \\
\hline D. cespitosa PI-577069 & c & G & $G / T$ & $\mathrm{~T}$ & G & $A / C$ & $A / C$ & $\mathrm{~T}$ & G & G & A \\
\hline D. cespitosa PI-371724 & $\mathrm{C}$ & G & $\mathrm{G} / \mathrm{T} / \mathrm{C}$ & $\mathrm{T} / \mathrm{A}$ & $\mathrm{G} / \mathrm{T}$ & A & $\mathrm{G} / \mathrm{C}$ & $\mathrm{T} / \mathrm{C}$ & G & G & A \\
\hline D. flexuosa PI-577075 & $\mathrm{C}$ & $\mathrm{G}$ & $\mathrm{G} / \mathrm{T}$ & $\mathrm{T}$ & G & $\mathrm{A}$ & $\mathrm{C}$ & $\mathrm{T}$ & $\mathrm{G} / \mathrm{T}$ & G & $\mathrm{A}$ \\
\hline D. elongata PI-665545 & $\mathrm{C}$ & G & $\mathrm{G} / \mathrm{T}$ & $\mathrm{T}$ & G & A & $\mathrm{C}$ & $T$ & $\mathrm{G} / \mathrm{T}$ & G & $\mathrm{A}$ \\
\hline D. danthonioides W6-39054 & $\mathrm{C}$ & $\mathrm{T}$ & $\mathrm{T}$ & $\mathrm{T}$ & G & $\mathrm{A}$ & $\mathrm{C}$ & $T$ & $G$ & $G$ & $\mathrm{~A}$ \\
\hline H. pubescens KEW- 065160 & $\mathrm{C}$ & G & $\mathrm{G} / \mathrm{T} / \mathrm{C}$ & $\mathrm{T}$ & G & $\mathrm{A} / \mathrm{C}$ & C & $\mathrm{T}$ & $G$ & $\mathrm{C} / \mathrm{G}$ & $\mathrm{A} / \mathrm{C}$ \\
\hline K. macrantha KEW-0096838 & C & G & C & A & $\mathrm{T}$ & A & G & c & G & G & A \\
\hline
\end{tabular}

Figure 1. Single-nucleotide alterations (red) revealed in the homologous regions of the obtained CON1 sequences.

\begin{tabular}{|c|c|c|c|c|c|c|c|c|}
\hline \multirow[t]{2}{*}{ Species } & \multicolumn{8}{|c|}{ Fragments with Single-Nucleotide Alterations Revealed in the Aligned CON2 Sequences } \\
\hline & TGAACAGTGCC & & TITGCGCTGGA & CTGGCGGIITI & TCACGAGGGAA & & & CAАACAGTTA \\
\hline Reference: D. antarctica & TGAACGGTGCC & CGGCGGTGTCA & ППTGСACTGGA & CTGGCAGTITT & TCACGGGGGAA & TITTGGgctac & GAGCGACGGTGG & CAQATAGTTA \\
\hline D. antarctica KEW-0522816 & $A / G$ & $\mathrm{G} / \mathrm{T}$ & G/A & G/A & $A / G$ & G & A & $\mathrm{C} / \mathrm{T}$ \\
\hline D. antarctica KEW-0661919 & $A / G$ & $G / T$ & G/A & G/A & $\mathrm{A} / \mathrm{G}$ & G & A & $\mathrm{C} / \mathrm{T}$ \\
\hline D. antarctica KEW-0521613 & $A / G$ & $G / T$ & G/A & G/A & $A / G$ & G & A & $\mathrm{C} / \mathrm{T}$ \\
\hline D. parvula KEW-0661849 & $\mathrm{A} / \mathrm{G}$ & $G / T$ & G/A & G/A & $\mathrm{A} / \mathrm{G}$ & G & A & $\mathrm{C} / \mathrm{T}$ \\
\hline D. sukatschewii 78 & A & G & A & G & A & $\mathrm{G} / \mathrm{C}$ & $\mathrm{A} / \mathrm{C}$ & $\mathrm{C}$ \\
\hline D. cespitosa PI-562652 & A & G & A & G & A & $\mathrm{G} / \mathrm{C}$ & $\mathrm{A} / \mathrm{C}$ & c \\
\hline D. cespitosa PI-577069 & A & G & A & G & A & $\mathrm{G} / \mathrm{C}$ & $\mathrm{A} / \mathrm{C}$ & $\mathrm{C}$ \\
\hline D. cespitosa PI- 371724 & A & G & A & G & A & $\mathrm{G} / \mathrm{C}$ & $\mathrm{A} / \mathrm{C}$ & $\mathrm{C}$ \\
\hline D. flexuosa PI-577075 & A & G & A & G & A & $\mathrm{G} / \mathrm{C}$ & $\mathrm{A} / \mathrm{C}$ & $\mathrm{C}$ \\
\hline D. elongata PI-665545 & A & G & A & G & A & $\mathrm{G} / \mathrm{C}$ & $\mathrm{A} / \mathrm{C}$ & $\mathrm{C}$ \\
\hline D. danthonioides W6-39054 & A & G & A & G & A & $\mathrm{G} / \mathrm{C}$ & $\mathrm{A}$ & $\mathrm{c}$ \\
\hline H. pubescens KEW-065160 & $\bar{A}$ & $\bar{G}$ & $\bar{A}$ & G & $\bar{A}$ & $G$ & $\bar{A}$ & $\mathrm{c}$ \\
\hline K. macrantha KEW-0096838 & A & G & A & G & A & G & A & $\mathrm{c}$ \\
\hline
\end{tabular}

Figure 2. Single-nucleotide alterations (red) revealed in the homologous regions of the obtained CON2 sequences.

\begin{tabular}{|c|c|c|c|c|c|c|c|c|c|}
\hline \multirow[t]{2}{*}{ Species } & \multicolumn{9}{|c|}{ Fragments with Single-Nucleotide Alterations Revealed in the Aligned COM2 Sequences } \\
\hline & & & ACACAGTITा & & & & & & GGTCCAGGGAC \\
\hline & CTCTCACGTCC & TIGGGATACTT & ACACATTITIT & CITTGAGAGG & GAACTCGTCGT & & & & GGTCCGGGGAC \\
\hline Reference: D. antarctica & CTCTCGCGTCC & TIGGGGTACT & ACACAATITाT & CIITTAGAGG & GAACTTGTCGT & GITCACGGCTA & CACGGCTATT & пाСTGGCCCT & GGTCCTGGGAC \\
\hline D. cespitosa PI-562652 & $A / G$ & $A / G$ & $\mathrm{G} / \mathrm{T} / \mathrm{A}$ & $G / T$ & $C / T$ & $\mathrm{C}$ & $\mathrm{C}$ & G & $A / G$ \\
\hline D. cespitosa PI-577069 & G & A & G & $G / T$ & $C / T$ & $\mathrm{C}$ & $\mathrm{C}$ & $\mathrm{G} / \mathrm{T}$ & $A / G$ \\
\hline D. parvula KEW-0661849 & G & A & $T / A$ & $\mathrm{G} / \mathrm{T}$ & $C / T$ & $\mathrm{C}$ & G & G & $A / G$ \\
\hline D. flexuosa PI-577075 & $\mathrm{A} / \mathrm{G}$ & $A / G$ & G/T/A & $\mathrm{G} / \mathrm{T}$ & $C / T$ & C & c & G & $A / G$ \\
\hline K. macrantha KEW-0096838 & $A / G$ & $\mathrm{~A} / \mathrm{G}$ & $\mathrm{G} / \mathrm{T}$ & $\mathrm{G} / \mathrm{T}$ & $\mathrm{C} / \mathrm{T}$ & $\mathrm{C} / \mathrm{A}$ & $\mathrm{C}$ & G & $A / T$ \\
\hline T. phleoides KEW- 0662385 & G & A & $T$ & $\mathrm{G} / \mathrm{T}$ & $T$ & $C / T$ & C/A & $G / A$ & $A / G$ \\
\hline
\end{tabular}

Figure 3. Single-nucleotide alterations (red) revealed in the homologous regions of the obtained COM2 sequences.

The performed BLAST (Basic Local Alignment Search Tool) analysis revealed high sequence homology between the obtained CON/COM DNAs and the reference DNA sequences of D. antarctica reported earlier [24]. CON1 sequences of the studied Deschampsia accessions together with Helictotrichon pubescens (Huds.) Pilg. (syn. Avenula pubescens (Hud.) Dumort.) showed 99\% homology with the reference DNA. CON1 sequences of $K$. macrantha and T. phleoides exhibited $95 \%$ and $93 \%$ similarity with the reference sequence, respectively. The homology of CON2 sequences for all available samples was $98-99 \%$. COM2 sequences of the studied Deschampsia species exhibited $99 \%$ sequence homology with the reference DNA, while COM2 sequences of K. macrantha and T. phleoides had 93\% and $95 \%$ similarity with the reference sequence, respectively.

The MSA (Multiple Sequence Alignment) analysis performed within the homologous regions, revealed eleven (in CON1), eight (in CON2), and nine (in COM2) fragments with 
single-nucleotide alterations (in homozygous and heterozygous states) (Figures 1-3). According to the patterns of MSA analyses for CON1 sequences, D. antarctica KEW-0522816, D. antarctica KEW-0661919, and D. parvula demonstrated uniform combinations of alterations (alteration profile) while D. antarctica KEW-0521613 had one distinct alteration (Figure 1). CON1 sequences of the other studied samples demonstrated unique profiles. It is noteworthy that CON1 sequences of DNA samples of D. sukatschewii, D. cespitosa PI-371724, D. cespitosa PI-562652, and H. pubescens exhibited triplets in heterozygous states (Figure 1).

Based on MSA analyses of CON2 sequences, we determined four groups of DNA samples. The first group included samples of $D$. antarctica KEW-0522816, D. antarctica KEW$0661919, D$. antarctica KEW-0521613, and D. parvula. In these samples, the alteration profiles were quite similar to the one observed in the reference CON2 sequence, and differed by just one alteration (column \#2) which appeared in the heterozygous state in DNA samples of the first group (in the reference sequence, it was in the homozygous state) (Figure 2).

The second group included DNA samples of D. sukatschewii, D. cespitosa PI-562652, D. cespitosa PI-577069, D. cespitosa PI-371724, D. elongata (Hook.) Munro, and D. flexuosa. The alteration profiles in these samples had only one match (column \#2) with the profile of the reference sequence, which was in the homozygous state. Five alterations (columns $\# 1,3,4,5,8$ ) were heterozygous in the reference sequence, while they were homozygous in samples of this group. The other two variations (columns \#6, 7) were heterozygous in samples of the second group but homozygous in the reference CON2 sequence (Figure 2).

The third group included DNA samples of $H$. pubescens and K. macrantha. Their profiles exhibited only homozygous alterations and consequently, they matched with the reference CON2 sequence in three (columns \#2,6,7) homozygous positions and differed in the rest of the alterations (columns $\# 1,3,4,5,8$ ), which were heterozygous in the reference sequence (Figure 2).

The fourth group included only a DNA sample of Deschampsia danthonioides (Trin.) Munro. Its alteration profile matched with the reference CON2 sequence in two homozygous positions (columns \#2, 7) and differed in six alterations. Five of them (columns \#1, 3, $4,5,8)$ were homozygous in $D$. danthonoiodes but they were heterozygous in the reference sequence; the sixth alteration (column \#6) was heterozygous in $D$. danthonoiodes but it was in a homozygous state in the reference CON2 sequence (Figure 2).

MSA analyses of the COM2 sequences demonstrated that all studied samples had unique alteration profiles (detailed in Figure 3).

Based on similarities and differences in the single-nucleotide alterations detected by MSA analyses in the homologous CON1, CON2, and COM2 regions, schematic trees demonstrating the inferred relationships among the studied accessions were built (Figure 4).

\subsection{Chromosomal Structural Variations in the Studied Accessions}

Karyotype analyses were performed in six species of Deschampsia: D. antarctica (KEW0521613), D. cespitosa (PI-371724), D. danthonioides, D. flexuosa, D. parvula, and D. sukatschewii. The studied accessions presented diploid karyotype with $2 n=26$ chromosomes with the exception of $D$. flexuosa with $2 n=28$ chromosomes (Figures 5-7). 
Multi-way DNA alignment.

Sequences: 13. Scoring matrix: Linear (Mismatch 2, OpenGap 4, ExtGap 1)
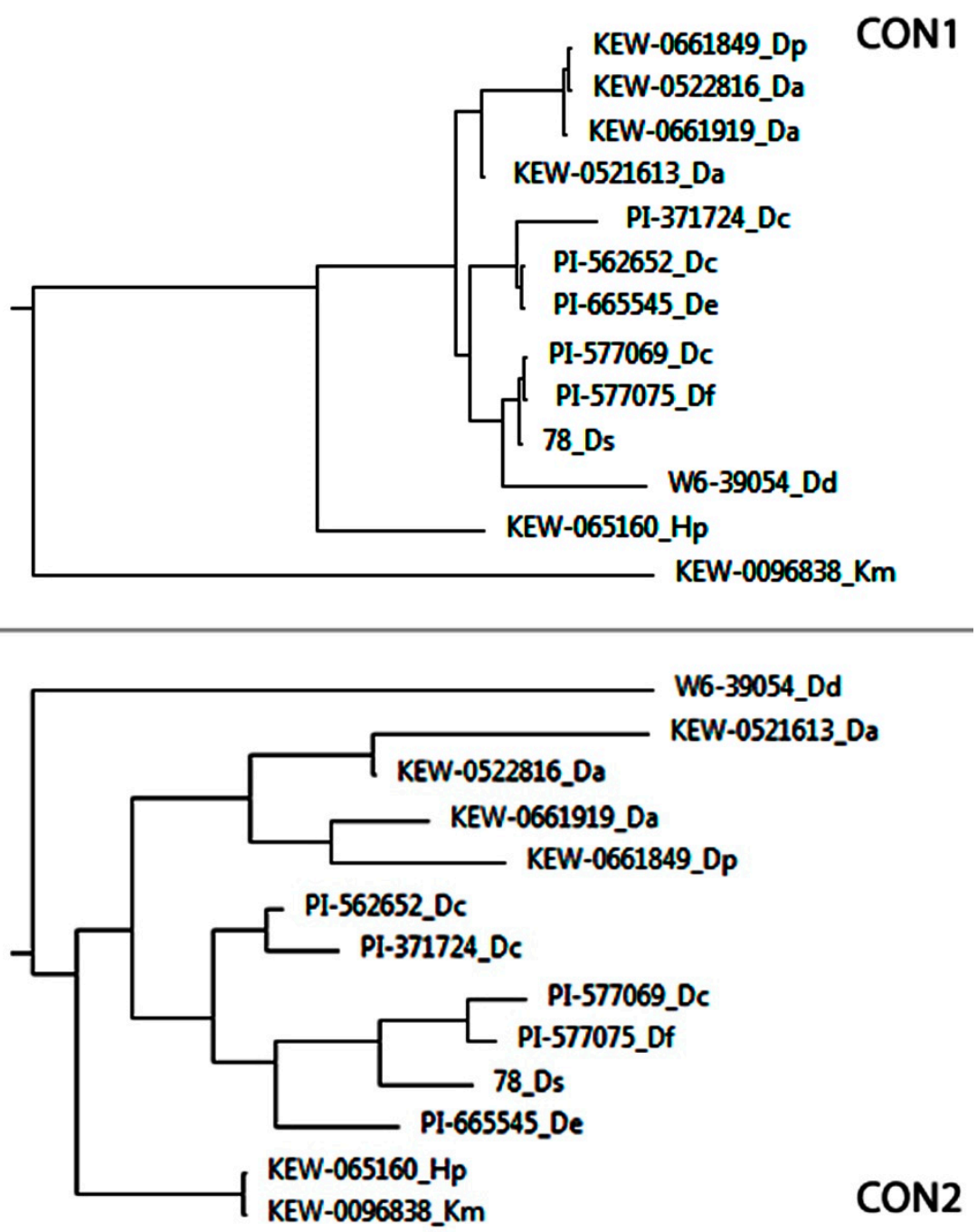

CON2

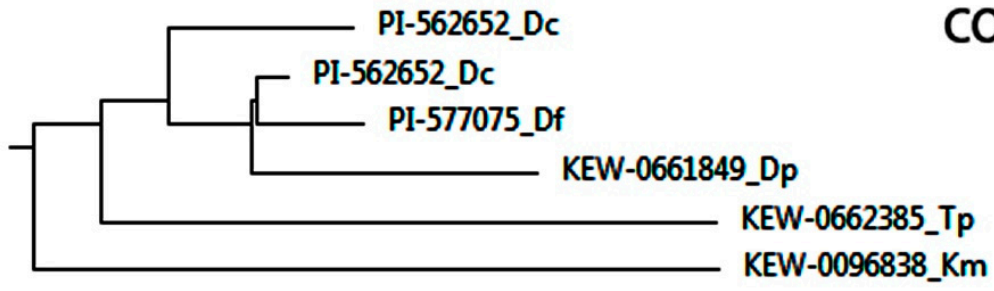

COM2

Figure 4. Schematic trees constructed according to the MSA analysis of the aligned CON1, CON2, and COM2 sequences. Da, Dc, Dd, De, Df, Dp, Ds, Hp, Km, and Tp-D. antarctica, D. cespitosa, D. danthonoiodes, D. elongata, D. flexuosa, D. parvula, D. sukatschewii, H. pubescens, K. macrantha, and T. phleoides, correspondingly. 


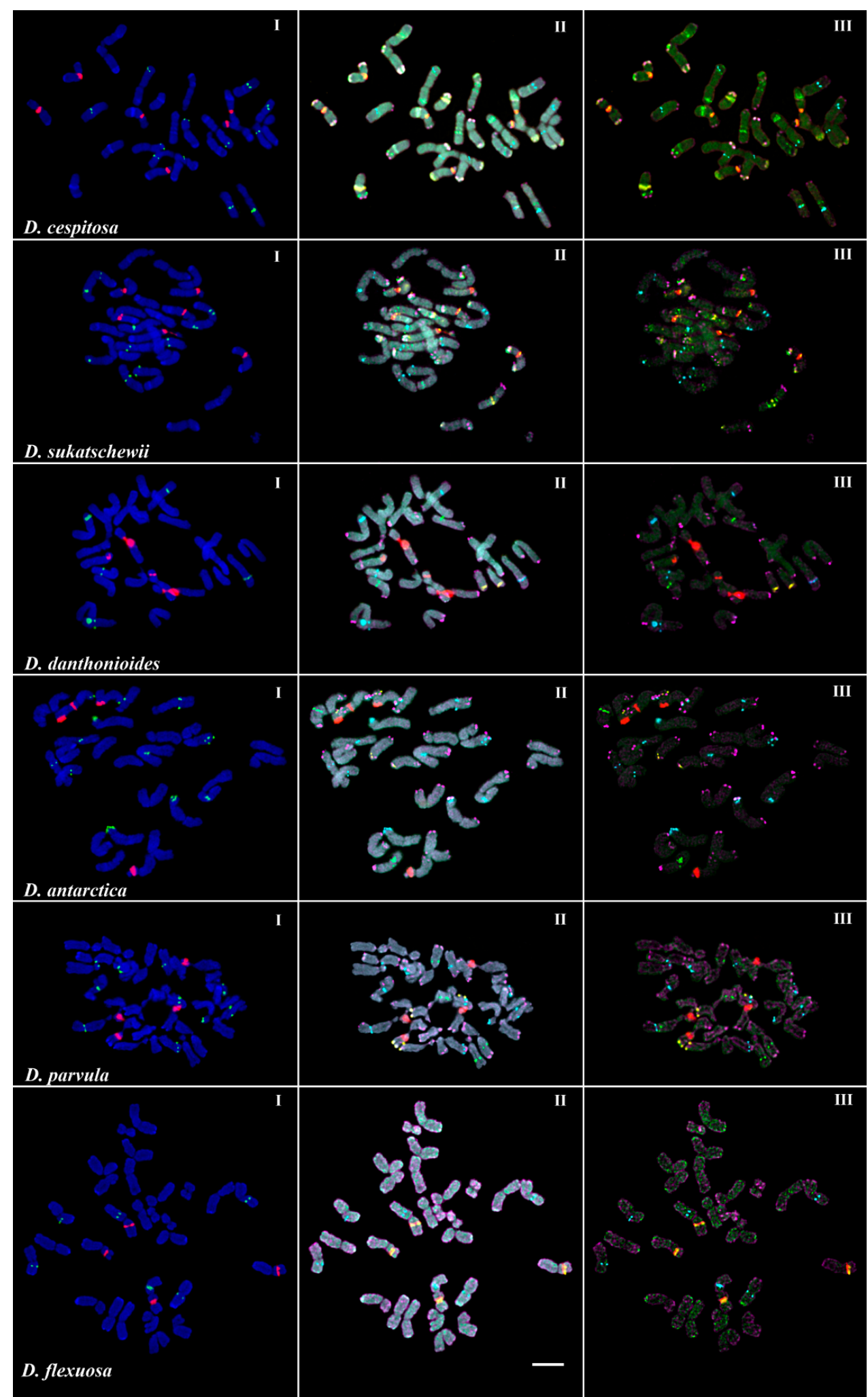

Figure 5. Chromosome spreads of the studied Deschampsia species. Merged fluorescent images after MC-FISH with (I) 45S rDNA (red) and 5S rDNA (green); (II) 45S rDNA (red), 5S rDNA (cyan), CON1 (yellow), CON2 (green), and COM2 (purple) satDNAs and also chromosomal DAPI-staining (gray); (III) 45S rDNA (red), 5S rDNA (cyan), CON1 (yellow), CON2 (green), and COM2 (purple) satDNAs. Scale bar- $5 \mu \mathrm{m}$. 


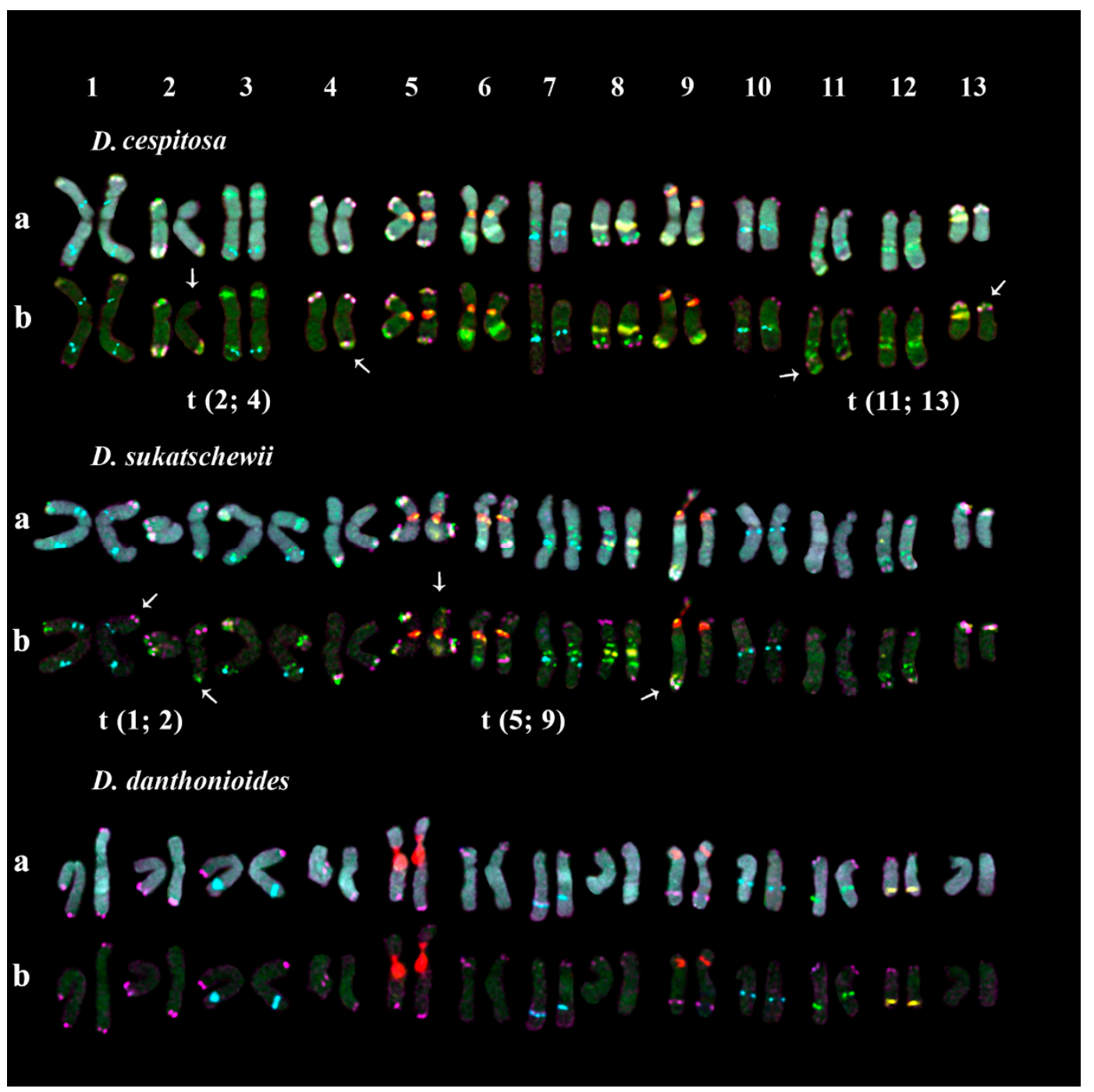

Figure 6. Karyotypes of D. cespitosa, D. sukatschewii, and D. danthonioides. Karyograms of the metaphase plates shown in Figure 5 after MC-FISH with (a) 45S rDNA (red), 5S rDNA (cyan), CON1 (yellow), CON2 (green), and COM2 (purple) satDNAs and also chromosomal DAPI-staining (gray) and (b) 45S rDNA (red), 5S rDNA (cyan), CON1 (yellow), CON2 (green), and COM2 (purple) satDNAs. Arrows point to chromosome rearrangements. 


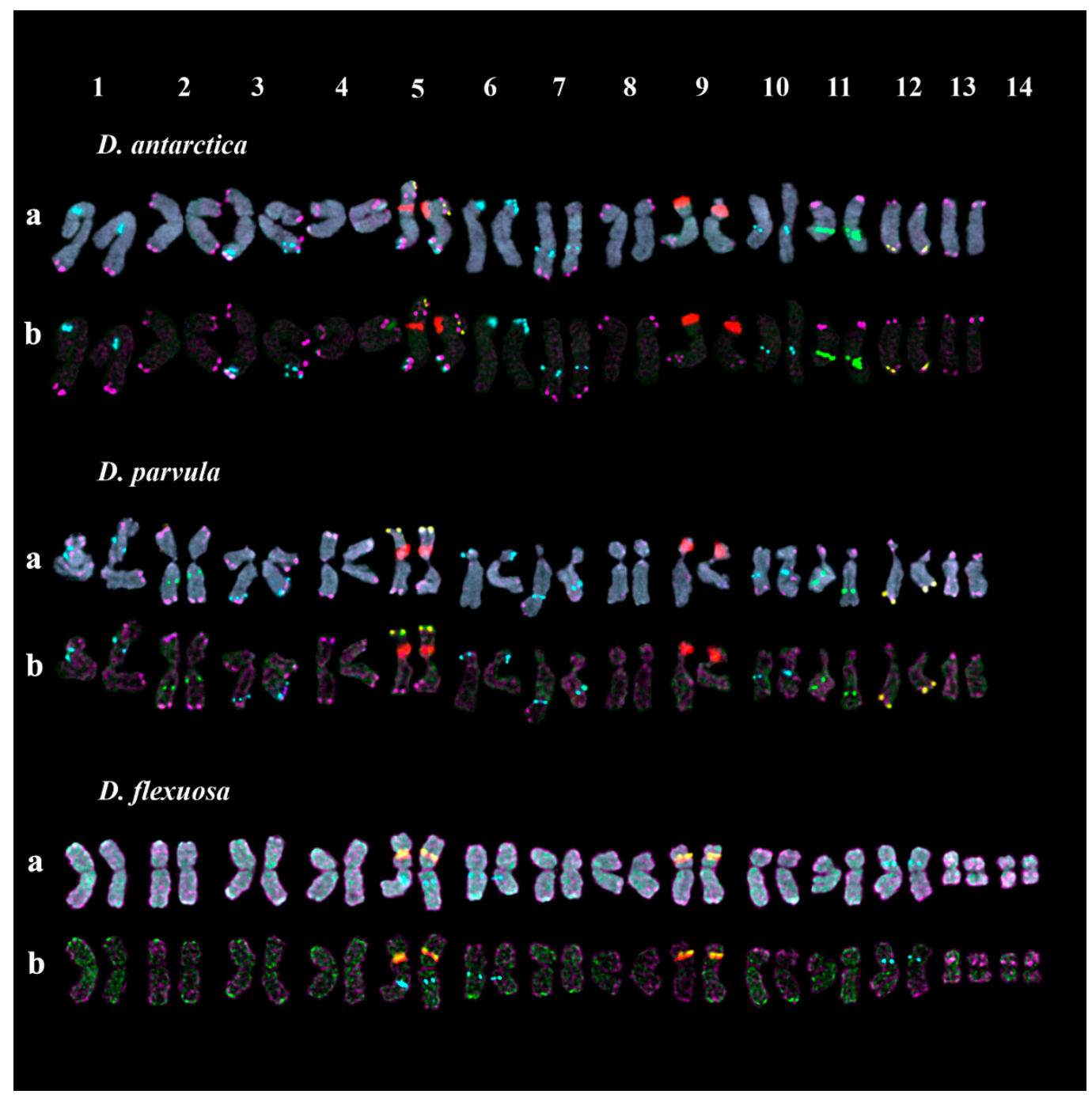

Figure 7. Karyotypes of D. antarctica, D. parvula and D. flexuosa. Karyograms of the metaphase plates shown in Figure 5 after MC-FISH with (a) 45S rDNA (red), 5S rDNA (cyan), CON1 (yellow), CON2 (green), and COM2 (purple) satDNAs and also chromosomal DAPI-staining (gray) and (b) 45S rDNA (red), 5S rDNA (cyan), CON1 (yellow), CON2 (green), and COM2 (purple) satDNAs.

In karyotypes of the studied D. cespitosa accession, FISH analysis revealed large 45S rDNA clusters in the secondary constriction regions (short arms) of three satellite (SAT) chromosome pairs 5, 6, and 9 . The satellites observed in chromosome pairs 5 and 6 were noticeably longer compared to chromosome pair 9. Additionally, ten 5S rDNA loci were detected on four chromosome pairs: 1 (two loci, in the proximal regions of the short and long arms), 3 (in the distal region of the long arm), and 7 and 10 (in the proximal regions of the long arms) (Figure 6). According to FISH, three satDNA families (CON1, CON2, and COM2) had multiple hybridization signals on chromosomes of the studied D. cespitosa accession. Both clustered and dispersed localization of CON1 and CON2 satDNAs were observed in different chromosome regions while clusters of COM2 satDNA were localized in the distal regions of most chromosomes. In the secondary constriction regions of the SAT chromosomes, CON1 clusters were co-localized with signals of $45 \mathrm{~S}$ rDNA. Based on the analysis of chromosome localization of these molecular cytogenetic markers, two chromosomal rearrangements $\mathrm{t}(2 ; 4)$ and $\mathrm{t}(11 ; 13)$ were detected. In both translocations, the subterminal chromosome regions with $\mathrm{CON} / \mathrm{COM}$ clusters were involved (Figure 6).

In the studied karyotypes of the D. sukatschewii accession, the pattern of distribution of $45 \mathrm{~S}$ and $5 \mathrm{~S}$ rDNA loci was similar to that observed in D. cespitosa. Multiple clustered and 
dispersed hybridization signals of CON1 and CON2 satDNAs were observed along the chromosomes though their positions differed slightly from those revealed in karyotypes of D. cespitosa. In the secondary constriction regions of the SAT chromosomes, CON1 clusters were co-localized with $45 \mathrm{~S}$ rDNA signals. Clusters of COM2 satDNA were revealed in the distal regions of most chromosomes. In the studied karyotypes of $D$. sukatschewii, two chromosomal translocations $(t(1 ; 2)$ and $t(5 ; 9))$ involving the subterminal chromosome regions with $\mathrm{CON} / \mathrm{COM}$ clusters were detected (Figure 6).

In the studied karyotypes of the $D$. danthonioides accession, large $45 \mathrm{~S}$ rDNA clusters were revealed in the secondary constriction regions (short arms) of two chromosome pairs, 5 and 9 (Figure 6). Clusters of 5S rDNA were detected on chromosome 3 (in the distal region of the long arm), and 7 and 10 (in the proximal regions of the long arms) (Figure 6). In the studied karyotypes, mostly clustered signals of CON/COM satDNAs were observed. Clusters of CON1 and CON2 satDNAs were localized in the long arms of chromosome pairs 12 (in the distal region) and 11 (in the proximal region), respectively. Clusters of COM2 satDNA were observed in the distal regions of most chromosomes (Figure 6).

In karyotypes of the studied $D$. antarctica and $D$. parvula accessions, patterns of chromosomal distributions of hybridization sites of 45S rDNA, $5 \mathrm{~S}$ rDNA, CON1, CON2, and $\mathrm{COM} 2$ repeats were rather similar. Large $45 \mathrm{~S}$ rDNA clusters were located in the secondary constriction regions (short arms) of two chromosome pairs, 5 and 9. The satellite observed in chromosome pair 5 was noticeably longer compared to chromosome pair 9. Clusters of $5 \mathrm{~S}$ rDNA were revealed in five chromosome pairs: 1 (in the proximal region of the short arm), 3 (in the distal region of the long arm), 6 (in the distal region of the short arm), and 7 and 10 (in the proximal regions of the long arms) (Figure 7). In D. antarctica mostly clustered signals of CON/COM satDNAs were revealed. In D. parvula, clustered and also dispersed signals of CON/COM satDNAs were observed. In both D. antarctica and D. parvula, two CON1 clusters, localized on chromosome pairs 5 (in the distal region of the satellite) and 12 (in the distal region of the long arm), were revealed, and one CON2 cluster was detected in the long arm of chromosome pair 11 (in the proximal region). Besides, in D. parvula, the second CON2 cluster was revealed in the long arm of chromosome pair 2 (in the proximal region). In both species, COM2 clusters were revealed in the distal regions of most chromosome pairs (Figure 7).

In the studied karyotypes of the D. flexuosa accession, large $45 \mathrm{~S}$ rDNA clusters were revealed in the secondary constriction regions (short arms) of two chromosome pairs, 5 and 9. Three hybridization sites of $5 \mathrm{~S}$ rDNA were detected on chromosome pair 5 (proximal region, long arm), 6 (proximal region, long arm), and 12 (proximal region, short arm) (Figure 7). Clusters of CON1 were observed on chromosome pairs 5 and 9 in the secondary constriction regions of the SAT chromosomes. Hybridization signals of CON2 and COM2 were mainly dispersed along the different chromosomes with the exception of several COM2 clusters revealed in the short arms (proximal regions) of chromosome pairs 13 and 14 (Figure 7).

\section{Discussion}

In genomes of most plants, satDNAs represent the most abundant fraction of repetitive sequences, and different classes of repetitive DNAs can spread along chromosomes and occupy chromosome-specific regions [21,29]. The evolution rate of repetitive DNAs is considered to be rather high [27,30,31]. The DNA repeats are often involved in chromosome rearrangements which can lead to genomic reorganization and contribute to the genetic diversity during evolution [21,31]. The comparative analysis of patterns of satDNA localization in karyotypes of the related plant species could provide insights into the evolutionary dynamics of chromosome structure variability during speciation within the genus [32]. In the present study, a detailed molecular cytogenetic analysis of Deschampsia species, based on MC-FISH with the use of different satDNA families as probes (45S rDNA, $5 \mathrm{~S}$ rDNA, CON1, CON2, and COM2), allowed us to study the specific patterns of their 
distribution in karyotypes, identify all homologous pairs of chromosomes and also detect chromosomal rearrangements.

High-copy-number $45 \mathrm{~S}$ and $5 \mathrm{~S}$ rDNAs have been found in genomes of all eukaryotes. These rDNA units comprise evolutionarily conserved sequences coding ribosomal rRNAs linked with variable intergenic spacer regions; that is why $45 \mathrm{~S}$ and $5 \mathrm{~S}$ rDNAs are widely used in plant phylogenetic studies in different taxonomic groups [33-35]. CON1, CON2, COM1, and COM2 satDNA families were initially obtained with restriction enzymes in Helictotrichon: CON1 (365 bp) and CON2 (562 bp) in H. convolutum, and COM1 (346 bp) and COM2 (476 bp) in H. compressum [26,27]. Additionally, CON/COM satDNAs were identified in genomes of other taxa of Aveneae/Poeae tribe complex including genera Arrhenatherum, Helictotrichon, Pseudarrhenatherum, and Trisetum $[15,28]$. The occurrence of CON1, CON2, COM1, and COM2 satDNAs in the genome of D. cespitosa were also detected earlier by a dot blot hybridization method [26,27]. However, only CON1, CON2, and COM2 were found in NGS genome sequence data of $D$. antarctica using bioinformatics methods [24]. Our findings are consistent with these data since we also could not reveal the COM1 element in genomes of the studied Deschampsia accessions using our approach. Previously, structural heterogeneity related to internal dynamics was detected in the COM1 sequence [29]; therefore, it cannot be excluded that during the evolution of the tribe, COM1 satDNA could change its structure significantly compared to the COM1 element originally detected in Helictotrichon $[26,27,36]$. Alternatively, the COM1 sequence may persist in the $D$. antarctica genome (as well as in genomes of other Deschampsia species) but not as a highly repetitive element [24].

In the present study, the obtained CON1, CON2, and COM2 DNA sequences of the studied Deschampsia accessions demonstrated high degree of homology with the reference DNA sequences. Our findings are also consistent with the earlier described data on high homology of CON/COM DNA sequences between D. antarctica and D. cespitosa accessions [25]. At the same time, we revealed different alteration profiles in homologous $\mathrm{CON} 1, \mathrm{CON} 2$, and COM2 regions of the studied samples. Moreover, based on the analysis of CON2 sequences, we observed clear division into groups among the studied Deschampsia accessions. These findings can be related to the interspecific genetic divergence which occurred in these satDNAs during the speciation process.

Recently, in D. antarctica accessions from various Antarctic and Patagonian populations, intraspecific variability in number and chromosomal localization of FISH signals of CON1, CON2, and COM2 repeats has been observed; this could be related to some evolutionary processes of differentiation in Deschampsia species complex in those regions [24]. One of those previously reported polymorphic variants of CON/COM chromosomal localization was basically consistent with our FISH results observed in karyotypes of D. antarctica accessions from the Falkland Islands. However, we did not detect intraspecific variability in patterns of chromosomal distribution of CON/COM repeats among the three examined $D$. antarctica accessions. At the same time, patterns of chromosomal distribution of signals of CON1 and CON2 satDNAs observed in the studied D. cespitosa accessions differed from the results reported earlier $[25,28]$. This could be related to high intraspecific genetic diversity revealed in this species [37,38].

In the studied Deschampsia species, patterns of chromosome distribution of CON1, CON2, and COM1 signals were different, which was probably related to the processes of speciation within the genus. In three (D. cespitosa, D. sukatschewii, and D. flexuosa) of the six studied species, CON1 clusters were co-localized with $45 \mathrm{~S}$ rDNA loci in the SAT chromosomes. In the studied accessions of D. cespitosa and D. sukatschewii, CON2 clusters were associated with $5 \mathrm{~S}$ rDNA loci. The relationship between chromosome localization of CON2 and $5 \mathrm{~S}$ rDNA clusters was reported earlier for several taxa of the genera Helictotrichon and Koeleria (related to Deschampsia); however, the low sequence homology between these monomers suggested their independent origin [28].

In the present study, the obtained CON/COM repeats demonstrated clustered and/or dispersed localization along chromosomes, which indicated that they could change their 
structure and organization in genomes during the species divergence. Particularly, in karyotypes of the studied accessions of D. cespitosa and D. sukatschewii, CON1 and CON2 signals were abundant demonstrating both clustered and dispersed localization on chromosomes. At the same time, only few CON1 and CON2 clusters were revealed in karyotypes of $D$. antarctica, $D$. danthonioides, and D. parvula. In D. flexuosa, CON2 signals were dispersed along different chromosomes, and COM2 loci presented both dispersed and clustered localization. Interestingly, in all studied species, COM2 clusters were abundant in number and mainly revealed in subterminal parts of most chromosomes. Subtelomeres are considered to be one of the most dynamic and rapidly evolving regions in eukaryotic genomes $[31,39,40]$. In different taxa of Aveneae/Poeae tribe complex, these chromosome regions comprise various families of repetitive DNA [41,42], and a significant part (about $60 \%$ ) of them are AT-rich repeated sequences [30,42-44]. It should be noted that $\mathrm{CON} / \mathrm{COM}$ clusters have AT-richness of $51-56 \%$ and often occur in AT-rich chromosome regions $[24,45]$. The AT-rich terminal satDNAs are suggested to perform some structural functions in a plant genome and contribute to the transition between telomeric domains and internal chromosomal regions [46,47]. Our results are consistent with this suggestion since the chromosomal translocations detected in karyotypes of the studied accessions of $D$. cespitosa and D. sukatschewii, involved the subterminal chromosome regions with $\mathrm{CON} / \mathrm{COM}$ cluster co-localization.

The similarity in monomer sizes and sequences revealed earlier between $D$. antarctica and Helictotrichon species (H. convolutum and H. compressum) indicated that CON1 and CON2 were more conserved than COM2 [24]. The COM2 element in D. antarctica (355 bp) was shown to comprise three sub-repeats of approximately $118 \mathrm{bp}$ while COM2 in H. compressum ( $474 \mathrm{bp}$ ) consisted of four $120 \mathrm{bp}$ sub-repeats indicating that some substructural changes might occur in COM2 DNAs during the divergence of Deschampsia species $[25,27]$.

It should be noted that patterns of FISH-based localization of CON1, CON2 and COM2 repeats on chromosomes of the studied Deschampsia species were basically similar to the patterns of the satDNA distribution revealed by rapid GISH with genomic DNA of D. cespitosa reported previously [16]. These results demonstrate that a rapid GISH approach is a useful tool for comparative karyotype analyses between related diploid plant species. At the same time, the rapid GISH method provided more signals of hybridization indicating the presence of a great number of common DNA repeats in their genomes.

The comparative analysis of chromosome morphology and patterns of distribution of the examined markers allowed us to divide the studied species into four karyological groups: (1) D. cespitosa, and D. sukatschewii; (2) D. antarctica and D. parvula; (3) D. danthonioides; (4) D. flexuosa, which is generally consistent with our previous data on the relationships between these species based on the rapid GISH approach [16].

In the present study, BLAST analysis confirmed the high degree of homology of the obtained CON1, CON2, and COM2 satDNAs with the reference sequences of $D$. antarctica. Based on the MSA analysis of the homologous CON/COM DNA regions, we revealed different groups of Deschampsia samples having uniform combinations of single-nucleotide alterations (though the division of the studied species into groups was slightly different). The schematic trees resulted from MSA analyses demonstrated the inferred relationships among the studied accessions based on similarities and differences in the single-nucleotide alterations. Particularly, all accessions of $D$. antarctica and D. parvula formed one common group according to $\mathrm{CON} 1$ and $\mathrm{CON} 2$ sequence alignment. The rest of the species formed different groups depending on the analyzed (CON1 or CON2) sequences.

It is noteworthy that the division of Deschampsia species into groups made in accordance with the patterns of CON/COM chromosomal distribution was basically consistent with the schematic trees resulting from the MSA analysis of CON2 sequences. The exception was $D$. flexuosa which belonged to the group of $D$. cespitosa complex according to the MSA analyses of CON1 and CON2 sequences, while it formed a separated group as a result of the analysis of patterns of CON/COM chromosomal localization. Additionally, 
the relationships between Deschampsia species resulting from the patterns of CON/COM chromosomal distribution basically agreed with the taxonomic and molecular phylogenetic studies of the genus Deschampsia inferred from nuclear ITS and plastid trnL sequence data reported earlier $[18,48]$. This highlights the importance of using a complex approach including the analysis of satDNAs and their chromosomal distribution for further taxonomic and phylogenetic studies within Deschampsia and other plant genera.

\section{Materials and Methods}

\subsection{Plant Material}

In the present study, we examined eleven Deschampsia accessions covering seven species and also three plant accessions representing other genera related to the genus Deschampsia (detailed in Table 1). Seeds of the studied species were germinated in Petri dishes with moist filter paper. Then the plants were grown in a greenhouse at $15^{\circ} \mathrm{C}$.

Table 1. The list of the studied plant accessions.

\begin{tabular}{|c|c|c|}
\hline Species & Catalog Number/Origin & Seed Source \\
\hline Deschampsiaantarctica E. Desv. & $\begin{array}{l}\text { KEW-0522816/Falkland Is., } \\
\text { St. Georgia }\end{array}$ & $\begin{array}{l}\text { Seed Conservation Department, Royal } \\
\text { Botanic Gardens, Kew, UK }\end{array}$ \\
\hline Deschampsiaantarctica E. Desv. & KEW-0661919/Falkland Is., Weddle & $\begin{array}{c}\text { Seed Conservation Department, Royal } \\
\text { Botanic Gardens, Kew, UK }\end{array}$ \\
\hline Deschampsiaantarctica E. Desv. & $\begin{array}{l}\text { KEW-0521613/Falkland Is., } \\
\text { St. Georgia }\end{array}$ & $\begin{array}{c}\text { Seed Conservation Department, Royal } \\
\text { Botanic Gardens, Kew, UK }\end{array}$ \\
\hline $\begin{array}{l}\text { Deschampsia cespitosa ssp. beringensis } \\
\text { (Hultén) W.E. Lawr. }\end{array}$ & PI-562652/Alaska, USA & $\begin{array}{c}\text { Western Regional Plant Introduction Station, } \\
\text { USDA ARS NPGS, Pullman, WA, USA }\end{array}$ \\
\hline Deschampsia cespitosa (L.) P. Beauv. & PI-371724/Alaska, Valdez. USA & $\begin{array}{l}\text { Western Regional Plant Introduction Station, } \\
\text { USDA ARS NPGS, Pullman, WA, USA }\end{array}$ \\
\hline Deschampsia cespitosa (L.) P. Beauv. & PI-577069/Great Britain & $\begin{array}{l}\text { Western Regional Plant Introduction Station, } \\
\text { USDA ARS NPGS, Pullman, WA, USA }\end{array}$ \\
\hline Deschampsia danthonioides (Trin.) Munro & W6-39054/Washington, USA & $\begin{array}{l}\text { Western Regional Plant Introduction Station, } \\
\text { USDA ARS NPGS, Pullman, WA, USA }\end{array}$ \\
\hline Deschampsia elongata (Hook.) & Munro PI-665545/Oregon, USA & $\begin{array}{l}\text { Western Regional Plant Introduction Station, } \\
\text { USDA ARS NPGS, Pullman, WA, USA }\end{array}$ \\
\hline $\begin{array}{c}\text { Deschampsia. flexuosa (L.) Trin. (= Avenella } \\
\text { flexuosa (L.) Drejer) }\end{array}$ & PI-577075/Wales, UK & $\begin{array}{l}\text { Western Regional Plant Introduction Station, } \\
\text { USDA ARS NPGS, Pullman, WA, USA }\end{array}$ \\
\hline Deschampsia parvula (Hook.f.) E. Desv. & KEW-0661849/Falkland Is. & $\begin{array}{c}\text { Seed Conservation Department, Royal } \\
\text { Botanic Gardens, Kew, UK }\end{array}$ \\
\hline Deschampsia sukatschewii (Popl.) Roshev & 78/Altai Mountains, RF & $\begin{array}{c}\text { Laboratory of genetic resources of fodder } \\
\text { plants, Federal Williams Research Center of } \\
\text { Forage Production and Agroecology (FWRC } \\
\text { FPA) }\end{array}$ \\
\hline $\begin{array}{l}\text { Helictotrichon pubescens (Huds.) Pilg. (syn. } \\
\text { Aenula pubescens (Hud.) Dumort.) }\end{array}$ & KEW-065160/England, UK & $\begin{array}{l}\text { Seed Conservation Department, Royal } \\
\text { Botanic Gardens, Kew, UK }\end{array}$ \\
\hline $\begin{array}{c}\text { Kolleria macrantha (Ledeb.) Schult. (syn. } \\
\text { Kolleria cristata (L.) Pers.) }\end{array}$ & KEW-0096838/Greece & $\begin{array}{c}\text { Seed Conservation Department, Royal } \\
\text { Botanic Gardens, Kew, UK }\end{array}$ \\
\hline Tricetum phleoides (d’Urv.) Kunth. & KEW-0662385/Falkland Is. & $\begin{array}{c}\text { Seed Conservation Department, Royal } \\
\text { Botanic Gardens, Kew, UK }\end{array}$ \\
\hline
\end{tabular}

\subsection{Genomic DNA Extraction, $P C R$, and Sequencing}

Genomic DNAs of the studied samples were isolated from fresh leaves using the Genomic DNA Purification kit (Thermo Fisher Scientific, Waltham, MA, USA). The DNA concentration and purification were assessed with the Implen Nano Photometer N50 (Implen, Munich, Germany).

The CON1, CON2, and COM2 DNA sequences were obtained by PCR amplification with the use of the primer pairs designed earlier for D. antarctica [24]. For designing primer pair COM1_F1 (5'-CGGGATAGTACACTTTGGAC-3') and COM1_R1 (5'GGAGACCGATGGATTTTC-3'), we used the COM1 DNA sequence of Helictotrichon com- 
pressum (ID pCOM1_1) (accession number Z68777.1) and Clone Manager 10 software (Sci Ed Software, Westminster, CO, USA).

The fragments of the target satDNAs were amplified under the following conditions: the reaction mix contained $1 \mu \mathrm{L}$ of template DNA (at least $30 \mathrm{ng}$ ), $5 \mathrm{pM}$ of each primer, $1 \mathrm{U}$ of Taq DNA polymerase (Sintol, Moscow, Russia), $2.5 \mu \mathrm{L}$ of $10 \times$ Taq buffer (Sintol, Moscow, Russia), $1.5 \mu \mathrm{L}$ of $25 \mathrm{mM} \mathrm{MgCl}_{2}$ (Sintol, Moscow, Russia), and $0.5 \mathrm{mM}$ of each dNTP (Silex, Moscow, Russia) in a total volume of $25 \mu \mathrm{L}$. The reactions were performed with the use of a T100 thermal cycler (Bio-rad, CA, USA) under the following cycle conditions: $3 \mathrm{~min}$ at $95^{\circ} \mathrm{C}$, followed by 35 cycles of $20 \mathrm{~s}$ at $95^{\circ} \mathrm{C}, 20 \mathrm{~s}$ at $60^{\circ} \mathrm{C}$, and $20 \mathrm{~s}$ at $72{ }^{\circ} \mathrm{C}$ with $5 \mathrm{~min}$ of a final extension at $72{ }^{\circ} \mathrm{C}$.

A total of $5 \mu \mathrm{L}$ of each amplified PCR products were separated by electrophoresis $(2.0 \%$ agarose gel containing $0.1 \%$ ethidium bromide at $100 \mathrm{~V}$ for $25 \mathrm{~min}$ ) and then visualized with the Bio-Rad Gel Doc XR + UV transilluminator (Bio-Rad, Hercules, CA, USA). The PCR product of COM1 satDNA was not used hereafter due to its unsatisfactory quality.

In case of the presence of one clear band on the gel, the rest of the PCR product $(20 \mu \mathrm{L})$ was purified by ethanol precipitation for further sequencing. If there was more than one band on the gel, the rest of the PCR product $(20 \mu \mathrm{L})$ underwent electrophoresis for further separation, then the band of the desired length was cut out from the gel and extracted using the QIAquick Gel Extraction Kit (Qiagen, Hilden, Germany).

The obtained and purified fragments of the CON1, CON2, and COM2 (with lengths of 333,538 , and 322 base pairs, respectively) were then Sanger sequenced using the automatic Applied Biosystems (ABI) 3730 DNA sequencer (Applied Biosystems, Foster City, CA, USA). The obtained sequences were analyzed with the use of Chromas 2.5 software (Technelysium Pty, South Brisbane, Australia). The homology of the obtained sequences with the reference DNAs was estimated by BLAST (Basic Local Alignment Search Tool) (NCBI, $\mathrm{MD}, \mathrm{USA}$ ). As reference DNA sequences, we used the CON1, CON2, and COM2 sequences of $D$. antarctica reported earlier [24]. Further MSA (Multiple Sequence Alignment) analyses were performed for detection single-nucleotide alterations in the aligned sequences of the obtained and reference CON/COM DNAs. Then, based on the MSA analyses performed in the homologous regions of the obtained $\mathrm{CON} / \mathrm{COM}$ sequences, schematic trees were built with the use of Clone Manager 10 software (Sci Ed Software, Westminster, CO, USA).

\subsection{Chromosome Spread Preparation}

For accumulation of mitotic divisions, root tips $(0.5-1 \mathrm{~cm}$ long) were incubated in ice water for $24 \mathrm{~h}$ and then fixed in the ethanol:glacial acetic acid fixative (3:1) for $48 \mathrm{~h}$ at room temperature. Fixed roots were stored in the fixative at $-20{ }^{\circ} \mathrm{C}$ before use.

Before spread preparation, the roots were put into $1 \%$ acetocarmine solution in $45 \%$ acetic acid for $40 \mathrm{~min}$. Then, on the object plate, the tip caps with root meristem were cut, macerated in a drop of $45 \%$ acetic acid, and covered with a cover slip. Then squashed chromosome preparations were made. The obtained preparations were frozen in liquid nitrogen to remove the cover slips, then dehydrated in the ethanol series $(70,85$, and $96 \%)$ and stored in $96 \%$ ethanol at $-20{ }^{\circ} \mathrm{C}$ before use.

\subsection{Fluorescence In Situ Hybridization}

- In FISH assays, the following probes were used:

- $\quad$ pTa71 containing a $9 \mathrm{~kb}$ long DNA sequence of common wheat enclosing 18S-5.8S-26S (45S) rDNA [49];

- $\quad$ Ta794 containing a 420 bp long DNA sequence of wheat containing 5S rDNA [50];

- $\quad$ CON1, CON2, and COM2 sequences obtained by the PCR-based technique.

These DNA probes were labeled directly with fluorochromes Aqua 431 dUTP, Red 594 dUTP, or Green 496 dUTP (Enzo Life Sciences, Lausen, Switzerland) by Nick translation according to manufacturers' protocols. The several sequential MC-FISH procedures were conducted with various combinations of these labeled DNA probes as described previously [51,52]. After FISH, chromosome slides were stained with 4',6-diamidino-2- 
phenylindole (DAPI) dissolved in the Vectashield mounting medium (Vector Laboratories, Burlingame, CA, USA) to a final concentration of $0.1 \mu \mathrm{g} / \mathrm{mL}$.

\subsection{Chromosomal Analysis}

The chromosome slides were examined with the use of the Olympus BX61 epifluorescence microscope (Olympus, Tokyo, Japan) coupled with a monochrome CCD camera (Snap, Roper Scientific, Tucson, AZ, USA). Chromosome images were collected in grayscale channels and pseudo-colored. Then they were processed using conventional Adobe Photoshop 10.0 (Adobe Systems, Birmingham, AL, USA) and VideoTesT-FISH 2.1 (IstaVideoTesT, St. Petersburg, Russia) software programs. At least 5 plants and 15 metaphase plates were examined in each sample. Based on the chromosome size and morphology and also distribution of chromosome markers, chromosome pairs in karyotypes were identified using the cytological nomenclature proposed earlier [16].

\section{Conclusions}

The obtained CON1, CON2, and COM2 satDNAs demonstrated high sequence homology between the studied Deschampsia species though their chromosomal distribution was different. These satDNAs can be used as specific markers for identification of chromosome pairs and detection of chromosomal rearrangements relevant for investigation of the genomic relationships within the genus Deschampsia. Our findings highlight the importance of changes which occurred in satDNA structures and their chromosomal disposition for clarifying the species divergence within this complex genus and also between related taxa. The obtained unique information on cytogenomic structures of Deschampsia species can serve as a basis for further genetic and phylogenetic studies, as well as for plant breeding.

Author Contributions: Conceptualization, A.V.A. and O.V.M.; formal analysis, A.V.A., L.G., S.A.Z., N.L.B., O.Y.Y. and T.E.S.; investigation, A.V.A., L.G., S.A.Z., N.L.B., O.Y.Y., T.E.S. and O.V.M.; methodology, O.V.M. and A.V.A.; supervision, O.V.M.; visualization, A.V.A., L.G., O.Y.Y., T.E.S. and S.A.Z.; writing-original draft, A.V.A., L.G., S.A.Z., O.Y.Y., T.E.S. and O.V.M.; writing-review and editing, A.V.A. and O.V.M. All authors have read and agreed to the published version of the manuscript.

Funding: This work was supported by the Russian Foundation of Basic Research (KOMFI project No. 1700-00336) and the Program of Fundamental Research of State Academies (project No. 121052000140-2).

Institutional Review Board Statement: Not applicable.

Informed Consent Statement: Not applicable.

Data Availability Statement: All data are contained within the article.

Acknowledgments: The authors acknowledge N.N. Kozlov and V.L. Korovina (Laboratory of genetic resources of fodder plants, FWRC of Forage Production and Agroecology, Lobnya, Moscow region, $\mathrm{RF}$ ) for providing us valuable plant materials.

Conflicts of Interest: The authors declare that they have no conflict of interest.

\section{References}

1. Tzvelev, N.N. Poaceae of the USSR; Nauka: Leningrad, Russia, 1976.

2. Soreng, R.J.; Peterson, P.M.; Romaschenko, K.; Davidse, G.; Zuloaga, F.O.; Judziewicz, E.J.; Filgueiras, T.S.; Davis, J.I.; Morrone, O. A worldwide phylogenetic classification of the Poaceae (Gramineae). J. Syst. Evol. 2015, 53, 117-137. [CrossRef]

3. Kellogg, E.A. Flowering plants. Monocots: Poaceae. In The Families and Genera of Vascular Plants; Kubitzki, K., Ed.; Springer: Cham, Switzerland, 2015; Volume XIII. [CrossRef]

4. Soreng, R.J.; Peterson, P.M.; Romaschenko, K.; Davidse, G.; Teisher, J.K.; Clark, L.G.; Barber, P.; Gillespie, L.J.; Zuloaga, F.O. A worldwide phylogenetic classification of the Poaceae (Gramineae) II: An update and a comparison of two 2015 classifications. J. Syst. Evol. 2017, 55, 259-290. [CrossRef]

5. Tzvelev, N.N. Arctic Flora of the USSR; Nauka: Leningrad, Russia, 1964; Volume 2.

6. Hulten, E. Flora of Alaska and Neighboring Territories; Stanford University Press: Stanford, UK, 1968.

7. Alberdi, M.; Bravo, L.A.; Gutierrez, A.; Gidekel, M.; Corcuera, L.J. Ecophysiology of Antarctic vascular plants. Physiol. Plant. 2002, 115, 479-486. [CrossRef] [PubMed]

8. Moore, D.M. Chromosome numbers of Falkland Islands angiosperms. BAS Bull. 1967, 14, 69-82. 
9. Moore, D.M. Studies in Colobanthus Quitensis (Kunth) Bartl. and Deschampsia antarctica Desv. II. Taxonomy, distribution and relationships. BAS Bull. 1970, 23, 63-80.

10. Chiapella, J.; Zuloaga, F.O. A Revision of Deschampsia, Avenella, and Vahlodea (Poaceae, Poeae, Airinae) in South America. Ann. Mo. Bot. Gard. 2010, 97, 141-162. [CrossRef]

11. Lee, J.; Noh, E.K.; Choi, H.S.; Shin, S.C.; Park, H.; Lee, H. Transcriptome sequencing of the Antarctic vascular plant Deschampsia antarctica Desv. under abiotic stress. Planta 2013, 237, 823-836. [CrossRef]

12. Long, Q.; Rabanal, F.A.; Meng, D.; Huber, C.D.; Farlow, A.; Platzer, A.; Zhang, Q.; Vilhjalmsson, B.J.; Korte, A.; Nizhynska, V.; et al. Massive genomic variation and strong selection in Arabidopsis thaliana lines from Sweden. Nat. Genet. 2013, 45, 884-890. [CrossRef]

13. Byun, M.Y.; Lee, J.; Cui, L.H.; Kang, Y.; Oh, T.K.; Park, H.; Lee, H.; Kim, W.T. Constitutive expression of DaCBF7, an Antarctic vascular plant Deschampsia antarctica CBF homolog, resulted in improved cold tolerance in transgenic rice plants. Plant Sci. 2015, 236, 61-74. [CrossRef]

14. Waminal, N.E.; Perumal, S.; Liu, S.; Chalhoub, B.; Kim, H.H.; Yang, T.J.; Liu, S.; Snowdon, R.; Chalhoub, B. Quantity, distribution, and evolution of major repeats in Brassica napus. In The Brassica Napus Genome; Liu, S., Snowdon, R., Chalhoub, B., Eds.; Springer International Publishing: Cham, Switzerland, 2018; pp. 111-129.

15. Roser, M.; Winterfeld, G.; Doring, E.; Schneider, J. Chromosome evolution in grass tribes Aveneae/Poeae (Poaceae): Insights from karyotype structure and molecular phylogeny. Schlechtendalia 2014, 28, 1-21.

16. Amosova, A.V.; Bolsheva, N.L.; Zoshchuk, S.A.; Twardovska, M.O.; Yurkevich, O.Y.; Andreev, I.O.; Samatadze, T.E.; Badaeva, E.D.; Kunakh, V.A.; Muravenko, O.V. Comparative molecular cytogenetic characterization of seven Deschampsia (Poaceae) species. PLoS ONE 2017, 12, e0175760. [CrossRef]

17. Soreng, R.J.; Davis, J.I. Phylogenetic structure in Poaceae subfamily Pooideae as inferred from molecular and morphological characters: Misclassification versus reticulation. In Grasses: Systematics and Evolution; Jacobs, S.W.L., Everett, J., Eds.; CSIRO Publishing: Collingwood, UK, 2000; pp. 61-74.

18. Saarela, J.M.; Bull, R.D.; Paradis, M.J.; Ebata, S.N.; Peterson, P.M.; Soreng, R.J.; Paszko, B. Molecular phylogenetics of cool-season grasses in the subtribes Agrostidinae, Anthoxanthinae, Aveninae, Brizinae, Calothecinae, Koeleriinae and Phalaridinae (Poaceae, Pooideae, Poeae, Poeae chloroplast group 1). PhytoKeys 2017, 87, 1-139. [CrossRef]

19. Amosova, A.V.; Bolsheva, N.L.; Samatadze, T.E.; Twardovska, M.O.; Zoshchuk, S.A.; Andreev, I.O.; Badaeva, E.D.; Kunakh, V.A.; Muravenko, O.V. Molecular cytogenetic analysis of Deschampsia antarctica Desv. (Poaceae), Maritime Antarctic. PLoS ONE 2015, 10, e0138878. [CrossRef]

20. Androsiuk, P.; Chwedorzewska, K.J.; Dulska, J.; Milarska, S.; Giełwanowska, I. Retrotransposon based genetic diversity of Deschampsia antarctica Desv. from King George Island (Maritime Antarctic). Ecol. Evol. 2021, 11, 648-663. [CrossRef]

21. Flavell, R.B.; O’Dell, M.; Hutchinson, J. Nucleotide sequence organization in plant chromosomes and evidence for sequence translocation during evolution. Cold Spring Harb. Symp. Quant. Biol. 1981, 45, 501-508. [CrossRef]

22. Mehrotra, S.; Goyal, V. Repetitive sequences in plant nuclear DNA: Types, distribution, evolution and function. Genom. Proteom. Bioinform. 2014, 12, 164-171. [CrossRef] [PubMed]

23. Tomas, D.; Rodrigues, J.; Varela, A.; Veloso, M.M.; Viegas, W.; Silva, M. Use of repetitive sequences for molecular and cytogenetic characterization of Avena species from Portugal. Int. J. Mol. Sci. 2016, 7, 203. [CrossRef] [PubMed]

24. González, M.L.; Chiapella, J.O.; Urdampilleta, J.D. Characterization of some satellite DNA families in Deschampsia antarctica (Poaceae). Polar Biol. 2018, 41, 457-468. [CrossRef]

25. González, M.L.; Chiapella, J.O.; Urdampilleta, J.D. Genomic differentiation of Deschampsia antarctica and D. cespitosa (Poaceae) based on satellite DNA. Bot. J. Linn. Soc. 2020, 194, 326-341. [CrossRef]

26. Grebenstein, B.; Grebenstein, O.; Sauer, W.; Hemleben, V. Characterization of a highly repeated DNA component of perennial oats (Helictotrichon, Poaceae) with sequence similarity to a A-genome-specific satellite DNA of rice (Oryza). Theor. Appl. Genet. 1995, 90, 1101-1105. [CrossRef]

27. Grebenstein, B.; Grebenstein, O.; Sauer, W.; Hemleben, V. Distribution and complex organization of satellite DNA sequences in Aveneae species. Genome 1996, 39, 1045-1050. [CrossRef]

28. Winterfeld, G.; Röser, M. Chromosomal localization and evolution of satellite DNAs and heterochromatin in grasses (Poaceae), especially tribe Aveneae. Plant Syst. Evol. 2007, 264, 75-100. [CrossRef]

29. Plohl, M.; Meštrović, N.; Mravinac, B. Satellite DNA evolution. Genome Dyn. 2012, 7, 126-152.

30. Flavell, R.B. Repetitive DNA and chromosome evolution in plants. Philos. Trans. R. Soc. Lond. B 1986, 312, $227-242$.

31. Carrido-Ramos, M. Satellite DNA in plants: More than just rubbish. Cytogenet Genome Res 2015, 146, 153-170. [CrossRef] [PubMed]

32. Ta, T.D.; Waminal, N.E.; Nguyen, T.H.; Pellerin, R.J.; Kim, H.H. Comparative FISH analysis of Senna tora tandem repeats revealed insights into the chromosome dynamics in Senna. Genes Genom. 2021, 43, 237-249. [CrossRef]

33. Volkov, R.A.; Medina, F.J.; Zentgraf, U.; Hemleben, V. Molecular cell biology: Organization and molecular evolution of rDNA, nucleolar dominance, and nucleolus structure. Prog. Bot. 2004, 65, 106-146.

34. Volkov, R.A.; Panchuk, I.I.; Borisjuk, N.V.; Hosiawa-Baranska, M.; Maluszynska, J.; Hemleben, V. Evolutional dynamics of 45S and 5 S ribosomal DNA in ancient allohexaploid Atropa belladonna. BMC Plant Biol. 2017, 17, 21. [CrossRef] 
35. Garcia, S.; Kovařík, A.; Leitch, A.R.; Garnatje, T. Cytogenetic features of rRNA genes across land plants: Analysis of the Plant rDNA database. Plant J. 2017, 89, 1020-1030. [CrossRef] [PubMed]

36. Ugarković, Đ. Satellite DNA libraries and centromere evolution. Open Evol. J. 2008, 2, 1-6. [CrossRef]

37. Kawano, S. Cytogeography and evolution of the Deschampsia caespitosa complex. Can. J. Bot. 1963, 41, 719-742. [CrossRef]

38. Garsia-Suarez, R.; Alonso-Blanco, C.; Fernandez-Carvajal, M.C.; Fernandez-Prieto, J.A.; Roca, F.; Giraldez, R. Diversity and systematics of Deschampsia sensu lato (Poaceae), inferred from karyotypes, protein electrophoresis, total genomic DNA hybridization and chloroplast DNA analysis. Plant Syst. Evol. 1997, 205, 99-110. [CrossRef]

39. Torres, G.A.; Gong, Z.; Iovene, M.; Hirsch, C.D.; Buell, C.R.; Bryan, G.J.; Novák, P.; Macas, J.; Jiang, J. Organization and evolution of subtelomeric satellite repeats in the potato genome. G3 Genes Genomes Genet. 2011, 1, 85-92. [CrossRef]

40. Richard, M.M.S.; Chen, N.W.G.; Thareau, V.; Pflieger, E.; Blanchet, S.; Bryan, G.J.; Novák, P.; Macas, J.; Jiang, J. The subtelomeric khipu satellite repeat from Phaseolus vulgaris: Lessons learned from the genome analysis of the Andean genotype G19833. Front Plant. Sci. 2013, 4, 109. [CrossRef]

41. Vershinin, A.V.; Schwarzacher, T.; Heslop-Harrison, J.S. The largescale genomic organization of repetitive DNA families at the telomeres of rye chromosomes. Plant Cell 1995, 7, 1823-1833. [PubMed]

42. Sharma, S.; Raina, S.N. Organization and evolution of highly repeated satellite DNA sequences in plant chromosomes. Cytogenet Genome Res. 2005, 109, 15-26. [CrossRef]

43. Kubis, S.; Schmidt, T.; Heslop-Harrison, J.S. Repetitive DNA elements as a major component of plant genomes. Ann. Bot. 1998, 82, 45-55. [CrossRef]

44. Macas, J.; Mészáros, T.; Nouzová, M. PlantSat: A specialized database for plant satellite repeats. Bioinformatics 2002, 18, 28-35. [CrossRef] [PubMed]

45. González, M.L.; Urdampilleta, J.D.; Fasanella, M.; Premoli, A.C.; Chiapella, J.O. Distribution of rDNA and polyploidy in Deschampsia antarctica E. Desv. in Antarctic and Patagonic populations. Polar Biol. 2016, 39, 1663-1677. [CrossRef]

46. Trifonov, E.N. The multiple codes of nucleotide sequences. Bull. Math. Biol. 1989, 51, 417-432. [CrossRef]

47. Sýkorová, E.; Fajkus, J.; Ito, M.; Fukui, K. Transition between two forms of heterochromatin at plant subtelomeres. Chromosome Res. 2001, 9, 309-323. [CrossRef]

48. Chiapella, J. A molecular phylogenetic study of Deschampsia (Poaceae: Aveneae) inferred from nuclear ITS and plastid trnL sequence data: Support for the recognition of Avenella and Vahlodea. Taxon 2007, 56, 55-64.

49. Gerlach, W.L.; Bedbrook, J.R. Cloning and characterization of ribosomal RNA genes from wheat and barley. Nucleic Acids Res. 1979, 7, 1869-1885. [CrossRef] [PubMed]

50. Gerlach, W.L.; Dyer, T.A. Sequence organization of the repeating units in the nucleus of wheat which contain $5 \mathrm{~S}$ rRNA genes. Nucleic Acids Res. 1980, 8, 4851-4855. [CrossRef] [PubMed]

51. Muravenko, O.V.; Yurkevich, O.Y.; Bolsheva, N.L.; Samatadze, T.E.; Nosova, I.V.; Zelenina, D.A.; Volkov, A.A.; Popov, K.V.; Zelenin, A.V. Comparison of genomes of eight species of sections Linum and Adenolinum from the genus Linum based on chromosome banding, molecular markers and RAPD analysis. Genetica 2009, 135, 245-255. [CrossRef] [PubMed]

52. Amosova, A.V.; Zoshchuk, S.A.; Rodionov, A.V.; Ghukasyan, L.; Samatadze, T.E.; Punina, E.O.; Loskutov, I.G.; Yurkevich, O.Y.; Muravenko, O.V. Molecular cytogenetics of valuable Arctic and sub-Arctic pasture grass species from the Aveneae/Poeae tribe complex (Poaceae). BMC Genet. 2019, 20, 92. [CrossRef] [PubMed] 